\title{
Practising Personalized Medicine in Asthma
}

\author{
Gareth Hynes, MD, Rahul Shrimanker, MD and Prof. lan D. Pavord, MD \\ Respiratory Medicine Unit, Nuffield Department of Medicine, University of Oxford, Oxford, UK
}

\section{ABSTRACT}

Asthma is a common and, in many cases, serious condition. After rapid improvement in outcomes following the introduction of the first guidelines in 1990, progress in this area has stalled. Current treatments follow a "one size fits all" approach without acknowledgement of the many different underlying disease mechanisms that drive the morbidity of asthma. Personalized medicine allows us to instead direct treatments at these specific causal mechanisms, targeting the exact pathology present in each patient. We believe that with this approach not only will we improve patient outcomes, we will also open the door to novel areas of research and drug discovery. In this article we describe where we are presently with the move towards personalized medicine in asthma, firstly explaining why we believe our current approach is insufficient, and secondly outlining in practical terms how physicians can adopt this novel approach when treating patients with asthma in clinics today. (BRN Rev. 2016;2:229-38)

Corresponding author: Ian Pavord, Ian.pavord@ndm.ox.ac.uk

Key words: Airway disease. Asthma. COPD. Personalised medicine. Precision medicine. Treatable traits. 


\section{INTRODUCTION}

The first recorded use of the term asthma, from the Greek aazein for panting, was by Hippocrates (460-370BC). It has, over time, evolved from a symptom-based descriptor to a more specific label, encompassing symptoms, abnormality of airway function, and airway inflammation. The asthma we recognise today is characterized by episodes of shortness of breath, wheeze, and cough due to airflow limitation as a result of an increased tendency of the airway to narrow (airway hyperresponsiveness), airway mucosal inflammation, and increased airway mucus production $^{1}$. It is a common, chronic inflammatory condition of the airways with prevalence rates ranging from $1-16 \%$ in different countries and affecting 300 million people worldwide ${ }^{2}$.

Asthma has, until recently, been viewed as a homogeneous condition and management has been applied in a "one size fits all" approach, using symptoms and measures of lung function to titrate therapy. However, recently it has become clear that our current classification system overgeneralizes a complex and heterogeneous mix of pathophysiologically distinct mechanisms (often known as endotypes) responsible for morbidity in patients with a label of asthma and results in treatment that is poorly targeted ${ }^{3-7}$. There is increasing interest in a new approach to stratification, which recognizes the clinical and biological complexity of airway disease and is clinically operationalized by treating, in a targeted fashion, components that can be recognized and modified (treatable traits) ${ }^{8}$. This approach paves the way for more personalized, efficient, and safe use of existing therapy. In this review we discuss the main drivers for a change in our management approach; suggest how a new targeted approach might be used in practise; and review evidence that this new personalized approach results in better patient outcomes and has been instrumental in the encouraging recent progress in new drug discovery.

\section{WHY CHANGE?}

Our current "one size fits all" approach to asthma management was formulated and adopted clinically following the publication of the first asthma guidelines 26 years ago-11. The key message -earlier and more aggressive use of inhaled corticosteroids- was strikingly effective and hospital admission rates and deaths from asthma halved in many developed countries over the next 10-15 years ${ }^{2}$. However, it is of concern that these outcomes have not improved much over the last 10 years, despite increased spending on treatment ${ }^{2}$. Asthma attacks still result in around 1,200 deaths every year in the UK, and the majority are the result of basic errors in asthma management and are thus readily preventable ${ }^{12}$. It is hard to escape the conclusion that this reflects poor targeting of treatment and/or an inability to sell the concept of prophylactic treatment to patients.

One potential explanation for stalling of improvements in outcome despite increased medication use is diagnostic imprecision. The diagnosis of asthma relies on the demonstration of variable airflow limitation. Airflow limitation can be measured by spirometry or peak flow meters, the latter being suitable for use at home and demonstrating variability over time. However, a large number of patients have acquired a label of "asthma" without 
any objective confirmation of variable airflow limitation ${ }^{13,14}$. This may be because there is no agreed definition of abnormal variability in airflow limitation. In addition, tests that are available are insufficiently sensitive to rule out the condition ${ }^{15}$ and can be difficult to carry out correctly in non-specialist settings, increasing the possibility of diagnostic error ${ }^{16}$. These factors have resulted in a pragmatic "trial of treatment" approach to diagnosis, which may have resulted in a large number of patients with transient, benign symptoms acquiring a label of asthma.

One key assumption made when adopting our current approach to management of asthma is that symptoms and abnormalities of airway function are directly and causally linked to eosinophilic airway inflammation. This is the basis for the step-wise symptomguided increases in corticosteroid use recommended by current guidelines ${ }^{1}$. New insights gained from the widespread use of noninvasive measures of airway inflammation have shown that this assumption is incorrect ${ }^{3-7}$. For example, eosinophilic airway inflammation, hitherto regarded as a defining characteristic of asthma, is in fact present in only $40-50 \%$ of patients, and its presence is not strongly associated with traditional measures including lung function and symptom scores ${ }^{3,17}$. Moreover, the same pattern of airway inflammation can be identified in patients with $\mathrm{COPD}^{18}$ and chronic cough ${ }^{19}$, conditions that are seen as distinct and are managed differently. The presence of eosinophilic airway inflammation is associated with the risk of attacks and the likely benefit of corticosteroid treatment ${ }^{3,4}$, so misclassification of pathology on the basis of our current classification system could be associated with suboptimal targeting of this treatment and outcomes that are worse than they could be.

There are additional practical difficulties in discriminating patients with asthma and a degree of fixed airflow limitation from those with COPD. This is an important consideration as current guideline-based strategies for use of inhaled corticosteroids differ markedly, with early use advocated for the former and late, risk-directed use advocated for the latter $^{1,20}$. Traditionally, these conditions are discriminated on the basis of demographics (atopy, smoking history, age of onset of symptoms) and the presence or absence of variable airflow limitation. However, there is no evidence that these characteristics are linked to the presence of eosinophilic airway inflammation and thus the risk of preventable exacerbations ${ }^{5,21}$. The current approach therefore has the potential to lead to inappropriate use of our most effective risk reduction strategy. Only a minority of patients with a diagnosis of asthma or COPD in the community have classic features as set out in guidelines and required for participation in the key clinical trials that have informed these guidelines $^{22,23}$. These trials are therefore poorly generalizable to the wider population with airway disease.

We suggest that 26 years after the introduction of guidelines, we have reached a turning point where the clinical community needs to decide if our current approach (more inhaled corticosteroids in more lungs) has delivered all it can, and whether we need to adopt an alternative, precision-based strategy predicated on a more detailed analysis of the mechanisms driving asthma outcomes (more inhaled corticosteroids in the right lungs). 


\section{PERSONALIZED MANAGEMENT OF AIRWAYS DISEASE}

We advocate breaking down the umbrella term "asthma" into its component parts, which in some cases might mean well-defined endotypes and in others more complex, less differentiated aspects. The identification and use of biomarkers that reflect underlying disease pathways is crucial to this process. Treatments can then be targeted to the pathways that are active and relevant to the individual patient. This approach requires recognizing traits that are identifiable and treatable. One example is eosinophilic airways inflammation, a readily identifiable and treatable trait. This approach requires us to accept that symptoms are not due to one process, and will not be amenable to one treatment paradigm. We strongly believe that this "label-free" personalized approach can be applicable and adaptable to all patients with airway disease in both primary and secondary care.

Table 1 lists some potential treatable traits. These traits vary in how easily they can be detected and their response to targeted treatments. Eosinophilic airway inflammation and variable airflow limitation due to bronchial hyperresponsiveness are both highly recognizable and treatable traits, with corticosteroid and anti-interleukin-5 (IL-5) treatment being very effective for the former ${ }^{24-26}$ and bronchodilator treatment for the latter ${ }^{27-29}$. Bronchiectasis, however, is also very recognizable, but the interventions and treatments for it have varying efficacy on asthma outcomes. Other traits, such as vocal cord dysfunction, can be harder to recognize, but do have effective treatment options once they are identified. These traits are not static as patients could have a single predominant or multiple traits at the same time and, with further pressure from changing environmental stimuli, aging or other developing comorbidities, could also have different traits at different times. The identification of these treatable traits should therefore be based on an iterative process involving repeated observations and measurements. The concepts could be extrapolated to aid in management of episodes of exacerbations of airway diseases ${ }^{30}$.

The approach need not add to the complexity of management of airway diseases as it could be adapted to different levels of care. For example, in primary care the focus could be on the two major treatable traits in patients with airway disease: eosinophilic airway inflammation and airflow limitation. The management algorithm would look similar to that suggested in the GOLD treatment pathway ${ }^{20}$, with the crucial difference that the focus will be on risk of exacerbations as a result of eosinophilic airway inflammation and day-to-day symptoms due to airflow limitation (Fig. 1). Using this approach, a patient with few symptoms but high markers of eosinophilic inflammation would appropriately be escalated to high-dose steroid treatment to minimize their exacerbation risk, whereas the patient with many symptoms but no inflammation would receive bronchodilators to improve symptoms but avoid corticosteroids which have been shown to be associated with pneumonia in this group ${ }^{31}$. This would result in more personalized and potentially more effective treatment, but would also highlight cases where neither pathway is active early on in the diagnostic process rather than after many months of fruitless asthma treatment. Two immediately obvious scenarios are the patient with symptoms not due to airflow limitation and 
TABLE 1.

\begin{tabular}{|c|c|c|c|c|c|}
\hline Trait & How to measure & Definition & Treatment & Clinical effect & $\begin{array}{l}\text { Strength } \\
\text { of effect }\end{array}$ \\
\hline $\begin{array}{l}\text { Airflow } \\
\quad \text { limitation }\end{array}$ & $\begin{array}{l}\text { Spirometry (primary } \\
\text { care, respiratory } \\
\text { clinic or lung } \\
\text { function lab) }\end{array}$ & $\mathrm{FEV}_{1} / \mathrm{FVC}$ ratio of $<0.7$ & $\begin{array}{l}\text { 1. Bronchodilators (LABA, } \\
\text { LAMA or LABA/LAMA) } \\
\text { 2. ICS } \\
\text { 3. Bronchial thermoplasty }\end{array}$ & $\begin{array}{l}\text { Improved daily symptoms, } \\
\text { reduction in number of } \\
\text { exacerbations, improved } \\
\text { lung function }\end{array}$ & $\begin{array}{l}\text { 1. }+++ \\
\text { 2. }+++ \\
\text { 3. }+\end{array}$ \\
\hline $\begin{array}{l}\text { Airway } \\
\text { hyperrespon- } \\
\text { siveness }\end{array}$ & $\begin{array}{l}\text { Methacholine } \\
\text { challenge } \\
\text { Bronchodilator } \\
\text { reversibility }\end{array}$ & $\begin{array}{l}\mathrm{PC} 20<8 \mathrm{mg} / \mathrm{ml} \\
\text { Improvement in } \mathrm{FEV}_{1} \text { of } 15 \% \\
\text { and/or } 200 \mathrm{ml}\end{array}$ & As above & & \\
\hline $\begin{array}{l}\text { Eosinophilic } \\
\text { airway } \\
\text { inflammation }\end{array}$ & $\begin{array}{l}\text { Induced sputum } \\
\text { Blood } \\
\text { FeNO }\end{array}$ & $\begin{array}{l}\text { Eosinophil count } \geq 3 \% \text { in sputum } \\
\text { Eosinophil count } \geq 2 \% \text { in blood } \\
\text { FeNO }>25 \mathrm{ppb}\end{array}$ & $\begin{array}{l}\text { 1. Corticosteroids (inhaled } \\
\text { or oral) } \\
\text { 2. Biologics (anti-IL5, anti-IgE) }\end{array}$ & $\begin{array}{l}\text { Reduction in exacerbations, } \\
\text { improved daily symptoms }\end{array}$ & $\begin{array}{l}\text { 1. }+++ \\
\text { 2. }+++\end{array}$ \\
\hline $\begin{array}{l}\text { Chronic airway } \\
\text { infection }\end{array}$ & $\begin{array}{l}\text { Sputum micros- } \\
\text { copy, culture and } \\
\text { sensitivity }\end{array}$ & $\begin{array}{l}\text { Colonisation of the airways } \\
\text { by bacteria }\end{array}$ & $\begin{array}{l}\text { Long-term low-dose macrolide } \\
\text { antibiotics }\end{array}$ & Reduction in exacerbations & ++ \\
\hline Bronchiectasis & CT scan & $\begin{array}{l}\text { Abnormal dilation of the small } \\
\text { airways predisposing } \\
\text { to excess sputum production } \\
\text { and infections }\end{array}$ & $\begin{array}{l}\text { 1. Airway clearance techniques } \\
\text { (e.g. physiotherapy) } \\
\text { 2. Mucolytics } \\
\text { 3. Macrolides } \\
\text { 4. Surgery in single lobe } \\
\text { bronchiectasis }\end{array}$ & $\begin{array}{l}\text { Reduction in daily sputum } \\
\text { production and number } \\
\text { of exacerbations }\end{array}$ & $\begin{array}{l}\text { 1. }++ \\
\text { 2. }+ \\
\text { 3. }++ \\
\text { 4. }+++ \text { (in } \\
\text { selected } \\
\text { patients) }\end{array}$ \\
\hline $\begin{array}{l}\text { Cough reflex } \\
\text { hypersensitiv- } \\
\text { ity }\end{array}$ & $\begin{array}{l}\text { A. Cough } \\
\text { questionnaire } \\
\text { B. Cough counts } \\
\text { C. Capsaicin } \\
\text { challenge }\end{array}$ & $\begin{array}{l}\text { A \& B > } 100 \text { coughs/day } \\
\text { C. Research tool, no defined } \\
\text { 'normal' value }\end{array}$ & $\begin{array}{l}\text { 1. Speech and language } \\
\text { therapy } \\
\text { 2. Gabapentin }\end{array}$ & $\begin{array}{l}\text { Reduction in cough frequency } \\
\pm \text { patient awareness } \\
\text { of cough }\end{array}$ & $\begin{array}{l}\text { 1. }++ \\
2 .+\end{array}$ \\
\hline Obesity & $\begin{array}{l}\text { Weight in kilograms } \\
\text { over height in } \\
\text { metres squared }\end{array}$ & $\mathrm{BMI}>30 \mathrm{~kg} / \mathrm{m}^{2}$ & $\begin{array}{l}\text { Diet } \\
\text { Exercise } \\
\text { Bariatric surgery }\end{array}$ & $\begin{array}{l}\text { Improved daily symptoms } \\
\text { and lung function, reduction } \\
\text { in severe exacerbations }\end{array}$ & ++ \\
\hline $\begin{array}{l}\text { Gastro-oesoph- } \\
\text { ageal reflux }\end{array}$ & $\begin{array}{l}\text { A. Patient account } \\
\text { B. Oesophageal } \\
\text { pH monitoring }\end{array}$ & $\begin{array}{l}\text { A. Symptoms } \\
\text { B. Significant drops } \\
\text { in oesophageal pH }\end{array}$ & $\begin{array}{l}\text { 1. Proton pump inhibitors } / \mathrm{H}_{2} \\
\text { antagonists } \\
\text { 2. Surgery }\end{array}$ & Improved daily symptoms & $\begin{array}{l}\text { 1. }+ \\
2 .+\end{array}$ \\
\hline $\begin{array}{l}\text { Upper airways } \\
\text { disease } \\
\text { (e.g. vocal cord } \\
\text { dysfunction) }\end{array}$ & $\begin{array}{l}\text { A. Laryngoscopy } \\
\text { B. Flow-volume } \\
\text { loop }\end{array}$ & $\begin{array}{l}\text { A. Paradoxical adduction } \\
\text { of vocal cords during } \\
\text { inspiration, expiration or both } \\
\text { B. Flattened inspiratory curve }\end{array}$ & $\begin{array}{l}\text { 1. Speech and language } \\
\text { therapy } \\
\text { 2. Psychotherapy }\end{array}$ & $\begin{array}{l}\text { Improved daily symptoms } \\
\text { and fewer exacerbations }\end{array}$ & $\begin{array}{l}\text { 1. }+++ \\
2 .+\end{array}$ \\
\hline Deconditioning & $\begin{array}{l}\text { Cardiopulmonary } \\
\text { exercise testing }\end{array}$ & $\begin{array}{l}\text { Reduced exercise capacity with } \\
\text { no pulmonary or cardiac } \\
\text { limitation }\end{array}$ & Exercise and education & $\begin{array}{l}\text { Improved daily symptoms } \\
\text { Unknown effect on } \\
\text { exacerbations }\end{array}$ & + \\
\hline $\begin{array}{l}\text { Poor treatment } \\
\text { adherence }\end{array}$ & $\begin{array}{l}\text { A. Prescription } \\
\text { monitoring } \\
\text { B. Chipped inhaler } \\
\text { devices } \\
\text { C. FeNO } \\
\text { suppression } \\
\text { testing }\end{array}$ & $\begin{array}{l}\text { A } / \mathrm{B} .<80 \% \text { adherence = poor } \\
\text { adherence } \\
<50 \% \text { adherence = very poor } \\
\text { adherence } \\
\text { C. FeNO value change over } \\
\text { a week when monitored } \\
\text { inhaler is used }\end{array}$ & $\begin{array}{l}\text { 1. Education } \\
\text { 2. FeNO suppression test } \\
\text { as educational tool } \\
\text { 3. IM corticosteroids in those } \\
\text { with eosinophilic disease } \\
\text { and poor adherence }\end{array}$ & $\begin{array}{l}\text { Improved daily symptoms, } \\
\text { reduction in exacerbations, } \\
\text { improved lung function }\end{array}$ & $\begin{array}{l}\text { 1. }+ \\
\text { 2. }++ \\
\text { 3. }+++ \text { (in } \\
\text { selected } \\
\text { patients) }\end{array}$ \\
\hline
\end{tabular}

+ Some effect of treatment or limited evidence of effect, ++ Moderate effect of treatment, +++ Good effect of treatment.

FeNO: fractional exhaled nitric oxide; FEV 1 ; forced expiratory volume in one second (litres); FVC: forced vital capacity (litres); ICS: inhaled corticosteroid; IgE: immunoglobulin E; IL-5: interleukin-5; LABA: long-acting beta agonist; LAMA: long-acting muscarinic antagonist; ppb: parts per billion; PC20: provocative concentration of inhalation agent resulting in a $20 \%$ drop in FEV 1 .

(Reproduced with permission from Agusti et al. ${ }^{8}$. 


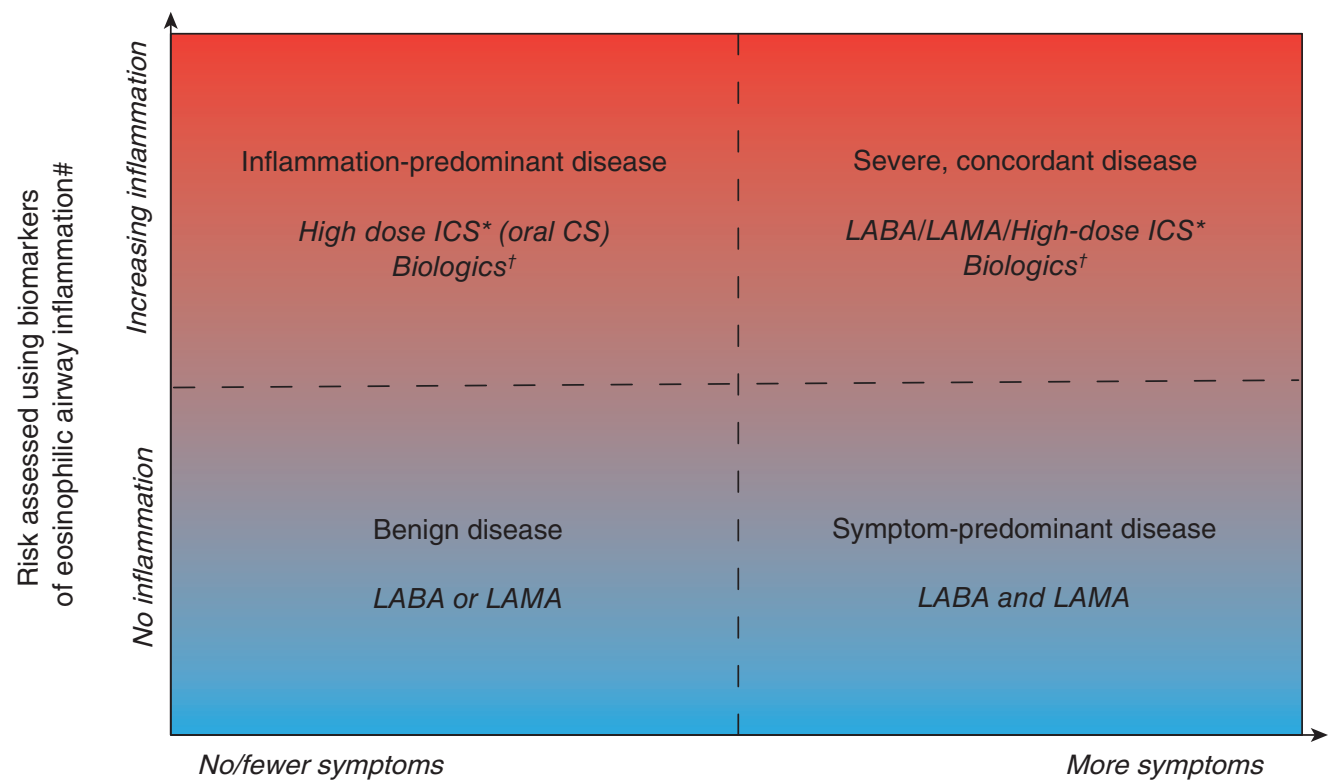

Symptoms due to airflow limitation

Figure 1. Proposed classification of airways diseases incorporating measures of eosinophilic airways inflammation and symptoms due to airflow limitation, and appropriate therapies based on this ${ }^{58}$.

*High-dose ICS as defined by the Global Initiative for Asthma ${ }^{59}$. ${ }^{\dagger}$ Biological monoclonal antibody therapy options include anti-IL-5 (mepolizumab) and anti-IL-4Ra (dupilumab). \#Biomarkers for eosinophilic airways inflammation include blood eosinophils $>3 \%$, sputum eosinophils $>2 \%$ or fractional exhaled nitric oxide $>25$ parts per billion.

CS: corticosteroids; ICS: inhaled corticosteroids; LABA: long-acting beta-agonists; LAMA: long-acting muscarinic receptor antagonists.

a patient with recurrent exacerbations with low biomarkers of eosinophilic airway inflammation. Cough reflex hypersensitivity is the most important cause of the former and infection-related neutrophilic airway inflammation is an important cause of the latter ${ }^{5}$.

\section{DOES PERSONALIZED MANAGEMENT RESULT IN BETTER OUTCOMES?}

Early studies investigating personalized management have been mostly of the proof-ofconcept type and have focused on the use of induced sputum eosinophil counts to personalize corticosteroid treatment in place of traditional clinical measures of symptoms and lung function. By and large, these studies have shown better patient outcomes and more economical use of treatment, irrespective of the patient group or context in which personalized treatment is given. Green et al. ${ }^{4}$ compared induced sputum-guided use of corticosteroid treatment with traditional guideline-based management in patients with severe asthma. Inflammation-guided management resulted in better control of eosinophilic airway inflammation over the 12-month study and a $67 \%$ reduction in the number of severe asthma 

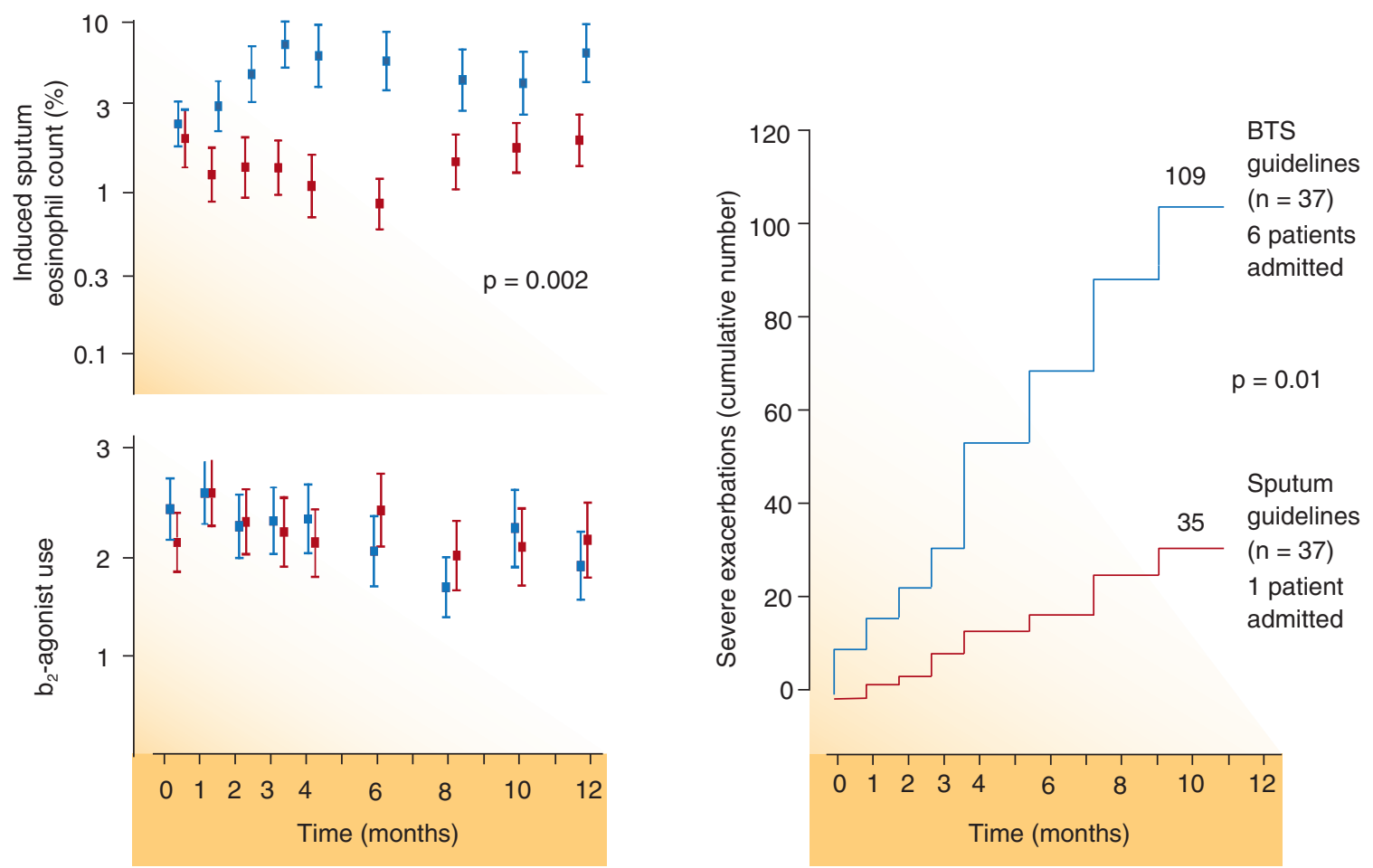

Figure 2. Induced sputum eosinophil counts, Beta2-agonist use and asthma exacerbations with traditional and sputum-guided personalized management of severe asthma ${ }^{4}$.

BTS: British Thoracic Society.

exacerbations in the sputum-guided treatment group (Fig. 2). Interestingly, while severe exacerbations, hospitalizations, and sputum eosinophil counts were markedly reduced, inhaled beta-2 agonist use was unchanged across both groups, reflecting the disconnect between asthma symptoms and exacerbation risk. Improved outcomes occurred with no overall increase in corticosteroid use, indicating better targeting of treatment with the personalized approach. Similar findings were reported by Jayaram et al. ${ }^{32}$ in a population with less severe asthma, and by Siva et al..$^{33}$ in patients with COPD. In the former study, the benefits of personalized, inflammation-targeted treatment was most obvious in patients with more severe asthma, a finding that could be explained by greater discordance between symptoms and eosinophilic airway inflammation in this population ${ }^{34}$.

Other more clinically accessible measures of eosinophilic airway inflammation have also been used as biomarkers to direct corticosteroid treatment. Exhaled nitric oxide (FeNO) is particularly attractive for this purpose as the test is easy to do and it provides an immediate result. The FeNO is increased in patients with eosinophilic airway inflammation as a result of IL-13-mediated induction of inducible nitric 
oxide synthase in the airway epithelium ${ }^{35}$. It is an excellent biomarker of response to inhaled corticosteroids $^{36}$, anti-IL-13 ${ }^{37}$, and anti-IgE ${ }^{38}$. Studies using FeNO to personalize asthma management have produced more mixed findings, probably because the populations, cut points for up and down titration of inhaled steroids, and management protocols have been suboptimal $^{39}$. Despite this, there is consistent evidence that FeNO-guided management results in fewer asthma exacerbations ${ }^{40,41}$ with potentially less treatment ${ }^{42}$. The best study was carried out in pregnant women with asthma and showed striking benefits, including a $60 \%$ reduction in asthma exacerbations during pregnancy, improved perinatal outcomes, and lower overall use of inhaled corticosteroids ${ }^{43}$.

The relationship between FeNO and eosinophilic airway inflammation is lost in current smokers ${ }^{44}$, suggesting that this technique will have less value in patients with COPD. However, the peripheral blood eosinophil count has emerged as an excellent marker of eosinophilic airway inflammation ${ }^{45}$, the risk of exacerbations $^{21}$, and the likely benefit of inhaled corticosteroids $^{21}$ in this population. Retrospective analyses of large phase III trials of inhaled corticosteroids in patients with moderate and severe COPD have shown that the benefit of inhaled corticosteroids added to long-acting beta agonists ${ }^{21,46,47}$ or alone ${ }^{48}$ on exacerbation numbers and decline in lung function are confined to patients with a blood eosinophil count $>2 \%$. The use of the blood eosinophil count to facilitate personalized management in patients with asthma has not yet been explored extensively, but there is compelling evidence that it is a prognostic marker ${ }^{26,49}$ and is associated with a positive response to anti-IL- $5^{26,50}$.
There has been less progress in more complex trials assessing the full extent to the personalized approach to management we advocate. McDonald et al. ${ }^{51}$ assessed a more ambitious approach based around three elements: inflammometry, multidimensional assessment to identify therapeutic targets, and case management to design and implement an individualized treatment programme. This tailored approach to treatment involved a multifaceted inflammometry intervention for airway diseases based on targeting eosinophilic inflammation, noneosinophilic pathways, and systemic inflammation. It was associated with preliminary evidence of more effective and economic use of currently available treatments in patients with COPD.

A personalized approach to airways disease will be essential if we are to make the most of the opportunities presented by the new biological era. Such an approach has been instrumental in the discovery of efficacy and is likely to be necessary for new drug discovery. We suggest that the shortcomings of our current approach to classification of airway diseases and the incorrect assumptions that are made when applying diagnostic labels are illustrated most compellingly by failures in new drug discovery over the last 60 years. A Medical Research Council study in 1956 of oral corticosteroids in asthma ${ }^{52}$ showed no benefit over bronchodilator treatment. This was a surprise to Dr Morrow Brown who had observed striking improvements in some of his patients. He conducted a further trial of oral corticosteroids in asthma in 1958 and found clear efficacy in patients with eosinophils in their sputum, but none in those without this feature $^{53}$. 
Another near miss is the case of the anti-IL-5 monoclonal antibody treatment, mepolizumab. Two of the earlier trials of mepolizumab showed that it dramatically reduced the blood and sputum eosinophil count in patients with asthma, but did not improve airway responsiveness, lung function, or quality of life ${ }^{54,55}$. The disappointing clinical effect of treatment led many to question whether eosinophilic inflammation played as important a role in asthma. However, other potential explanations for the observed lack of clinical efficacy was that the drug was being used in patients who did not have active eosinophilic inflammation, and that the trials were looking at the wrong outcomes. Patients with active eosinophilic disease are at risk of exacerbations and this increased risk is relatively independent of symptoms or decreased lung function ${ }^{4}$. It follows that reducing the amount of eosinophilic inflammation may not improve symptoms as much as exacerbation rate. This change in thinking led to the design and development of appropriate trials, in the right subjects, looking at the most responsive clinical outcomes resulting in the demonstration of dramatic improvements in exacerbation rates in subjects with eosinophilic asthma who are treated with mepolizumab ${ }^{56,57}$.

\section{CONCLUSION}

Our current approach to classification of airways disease is, we believe, no longer fit for purpose. It is impractical, overgeneralizes complex and heterogeneous conditions, and results in management that is imprecise and outcomes that are worse than they could be. Importantly, the assumptions we make when applying a diagnostic label have impeded new drug discovery and will continue to do so unless we change our approach. We suggest a new mechanism-based approach to airways disease classification and management where the emphasis is on identification of key causal mechanisms and targeted personalized intervention with treatment based on uncovering the relevant mechanism rather than an arbitrary label. We highlight two key treatable traits and suggest how they can be identified and managed in a personalized way, even in non-specialist healthcare settings. There are likely to be many more whose identification will follow once we remove the constraints imposed by our current out-dated classification system.

\section{REFERENCES}

1. Reddel HK, Bateman ED, Becker A et al. A summary of the new GINA strategy: a roadmap to asthma control. Eur Respir J. 2015;46:622-39.

2. Martinez FD, Vercelli D. Asthma. Lancet. 2013;382:1360-72.

3. Green RH, Brightling CE, Woltmann G, Parker D, Wardlaw AJ, Pavord ID. Analysis of induced sputum in adults with asthma: identification of subgroup with isolated sputum neutrophilia and poor response to inhaled corticosteroids. Thorax. 2002;57:875-9.

4. Green RH, Brightling CE, McKenna S et al. Asthma exacerbations and sputum eosinophil counts: a randomised controlled trial. Lancet. 2002;360: 1715-21.

5. Pavord ID. Complex airway disease: an approach to assessment and management. Lancet Respir Med. 2013;1:84-90.

6. Wenzel SE. Asthma: defining of the persistent adult phenotypes. Lancet. 2006;368:804-13.

7. Anderson GP. Endotyping asthma: new insights into key pathogenic mechanisms in a complex, heterogeneous disease. Lancet. 2008;372:1107-19.

8. Agusti A, Bel E, Thomas M et al. Treatable traits: toward precision medicine of chronic airway diseases. Eur Respir J. 2016;47:410-19.

9. International consensus report on diagnosis and treatment of asthma. National Heart, Lung, and Blood Institute, National Institutes of Health. Bethesda, Maryland 20892. Publication no. 92-3091, March 1992. Eur Respir J. 1992;5:601-41.

10. Woolcock A, Rubinfeld AR, Seale JP et al. Thoracic society of Australia and New Zealand. Asthma management plan, 1989. Med J Aust. 1989;151:650-3.

11. Guidelines for management of asthma in adults: I--Chronic persistent asthma. Statement by the British Thoracic Society, Research Unit of the Royal College of Physicians of London, King's Fund Centre, National Asthma Campaign. BMJ. 1990;301:651-3.

12. Levy ML, Winter R. Asthma deaths: what now? Thorax. 2015:70:209-10.

13. Joyce DP, Chapman KR, Kesten S. Prior diagnosis and treatment of patients with normal results of methacholine challenge and unexplained respiratory symptoms. Chest. 1996;109:697-701. 
14. Shaw D, Green R, Berry M et al. A cross-sectional study of patterns of airway dysfunction, symptoms and morbidity in primary care asthma. Prim Care Respir J. 2012;21:283-7.

15. Hunter CJ, Brightling CE, Woltmann G, Wardlaw AJ, Pavord ID. A comparison of the validity of different diagnostic tests in adults with asthma. Chest. 2002;121:1051-7.

16. Pavord ID, Shaw DE, Gibson PG, Taylor DR. Inflammometry to assess airway diseases. Lancet. 2008;372:1017-9.

17. Pavord ID, Brightling CE, Woltmann G, Wardlaw AJ. Non-eosinophilic corticosteroid unresponsive asthma. Lancet. 1999;353:2213-4.

18. Brightling CE, Monteiro W, Ward R et al. Sputum eosinophilia and shortterm response to prednisolone in chronic obstructive pulmonary disease: a randomised controlled trial. Lancet. 2000;356:1480-5.

19. Brightling CE, Pavord ID. Eosinophilic bronchitis: an important cause of prolonged cough. Ann Med. 2000;32:446-51.

20. Vestbo J, Hurd SS, Agusti AG et al. Global strategy for the diagnosis, management, and prevention of chronic obstructive pulmonary disease: GOLD executive summary. Am J Respir Crit Care Med. 2013;187:347-65.

21. Pascoe S, Locantore N, Dransfield MT, Barnes NC, Pavord ID. Blood eosinophil counts, exacerbations, and response to the addition of inhaled fluticasone furoate to vilanterol in patients with chronic obstructive pulmonary disease: a secondary analysis of data from two parallel randomised controlled trials. Lancet Respir Med. 2015;3:435-42.

22. Marsh SE, Travers J, Weatherall M et al. Proportional classifications of COPD phenotypes. Thorax. 2008;63:761-7.

23. Travers J, Marsh S, Williams M et al. External validity of randomised controlled trials in asthma: to whom do the results of the trials apply? Thorax. 2007;62:219-23

24. Pavord ID, Brightling CE, Woltmann G, Wardlaw AJ. Non-eosinophilic cor ticosteroid unresponsive asthma. Lancet. 1999;353:2213-4.

25. Little SA, Chalmers GW, MacLeod KJ, McSharry C, Thomson NC. Non-invasive markers of airway inflammation as predictors of oral steroid responsiveness in asthma. Thorax. 2000;55:232-4.

26. Pavord ID, Korn S, Howarth P et al. Mepolizumab for severe eosinophilic asthma (DREAM): a multicentre, double-blind, placebo-controlled trial. Lancet. 2012;380:651-9.

27. Kerstjens HA, Engel M, Dahl R et al. Tiotropium in asthma poorly controlled with standard combination therapy. N Engl J Med. 2012;367: 1198-207.

28. Parameswaran KN, Inman MD, Ekholm BP et al. Protection against methacholine bronchoconstriction to assess relative potency of inhaled beta2-agonist. Am J Respir Crit Care Med. 1999;160:354-7.

29. Page CP, Spina D. Beta2-agonists and bronchial hyperresponsiveness. Clin Rev Allergy Immunol. 2006;31:143-62.

30. Bafadhel M, McKenna S, Terry S et al. Blood eosinophils to direct corticosteroid treatment of exacerbations of chronic obstructive pulmonary disease: a randomized placebo-controlled trial. Am J Respir Crit Care Med. 2012;186:48-55

31. Pavord ID, Lettis S, Anzueto A, Barnes N. Blood eosinophil count and pneumonia risk in patients with chronic obstructive pulmonary disease: a patient-level meta-analysis. Lancet Respir Med. 2016. [Epub ahead of print].

32. Jayaram L, Pizzichini MM, Cook RJ et al. Determining asthma treatment by monitoring sputum cell counts: effect on exacerbations. Eur Respir J. 2006;27:483-94

33. Siva R, Green RH, Brightling CE et al. Eosinophilic airway inflammation and exacerbations of COPD: a randomised controlled trial. Eur Respir J. 2007;29:906-13

34. Haldar P, Pavord ID, Shaw DE et al. Cluster analysis and clinical asthma phenotypes. Am J Respir Crit Care Med. 2008;178:218-24.

35. Woodruff PG, Modrek B, Choy DF et al. T-helper type 2-driven inflammation defines major subphenotypes of asthma. Am J Respir Crit Care Med. 2009;180:388-95.

36. Smith AD, Cowan JO, Brassett KP et al. Exhaled nitric oxide: a predictor of steroid response. Am J Respir Crit Care Med. 2005;172:453-9.
37. Corren J, Lemanske RF, Hanania NA et al. Lebrikizumab treatment in adults with asthma. N Engl J Med. 2011;365:1088-98.

38. Hanania NA, Wenzel S, Rosen K et al. Exploring the effects of omalizumab in allergic asthma: an analysis of biomarkers in the EXTRA study. Am J Respir Crit Care Med. 2013;187:804-11.

39. Gibson PG. Using fractional exhaled nitric oxide to guide asthma therapy: design and methodological issues for ASthma TReatment ALgorithm studies. Clin Exp Allergy. 2009;39:478-90.

40. Essat M, Harnan S, Gomersall $\mathrm{T}$ et al. Fractional exhaled nitric oxide for the management of asthma in adults: a systematic review. Eur Respir J 2016;47:751-68

41. Petsky HL, Cates CJ, Lasserson TJ et al. A systematic review and meta-analysis: tailoring asthma treatment on eosinophilic markers (exhaled nitric oxide or sputum eosinophils). Thorax. 2012;67:199-208.

42. Smith AD, Cowan JO, Brassett KP, Herbison GP, Taylor DR. Use of exhaled nitric oxide measurements to guide treatment in chronic asthma. N Engl Med. 2005;352:2163-73

43. Powell H, Murphy VE, Taylor DR et al. Management of asthma in pregnancy guided by measurement of fraction of exhaled nitric oxide: a double-blind, randomised controlled trial. Lancet. 2011;378:983-90.

44. Berry MA, Shaw DE, Green RH, Brightling CE, Wardlaw AJ, Pavord ID. The use of exhaled nitric oxide concentration to identify eosinophilic airway inflammation: an observational study in adults with asthma. Clin Exp Allergy. 2005;35:1175-9.

45. Bafadhel M, McKenna S, Terry S et al. Acute exacerbations of chronic obstructive pulmonary disease: identification of biologic clusters and their biomarkers. Am J Respir Crit Care Med. 2011;184:662-71.

46. Pavord ID, Lettis $\mathrm{S}$, Locantore $\mathrm{N}$ et al. Blood eosinophils and inhaled corticosteroid/long-acting beta-2 agonist efficacy in COPD. Thorax. 2016;71:118-25

47. Siddiqui SH, Guasconi A, Vestbo J et al. Blood Eosinophils: A biomarker of response to extrafine beclomethasone/formoterol in chronic obstructive pulmonary disease. Am J Respir Crit Care Med. 2015;192:523-5.

48. Barnes NC, Sharma R, Lettis S, Calverley PM. Blood eosinophils as a marker of response to inhaled corticosteroids in COPD. Eur Respir J. 2016;47:1374-82.

49. Price DB, Rigazio A, Campbell JD et al. Blood eosinophil count and prospective annual asthma disease burden: a UK cohort study. Lancet Respir Med. 2015;3:849-58.

50. Ortega HG, Yancey SW, Mayer B et al. Severe eosinophilic asthma treated with mepolizumab stratified by baseline eosinophil thresholds: a secondary analysis of the DREAM and MENSA studies. Lancet Respir Med. 2016;4 549-56.

51. McDonald VM, Higgins I, Wood LG, Gibson PG. Multidimensional assessment and tailored interventions for COPD: respiratory utopia or common sense? Thorax. 2013;68:691-4.

52. Medical Research Council. Controlled trial of effects of cortisone acetate in chronic asthma; report to the Medical Research Council by the subcommit tee on clinical trials in asthma. Lancet. 1956;271:798-803.

53. Brown HM. Treatment of chronic asthma with prednisolone; significance of eosinophils in the sputum. Lancet. 1958;2:1245-7.

54. Leckie MJ, ten Brinke A, Khan J et al. Effects of an interleukin-5 blocking monoclonal antibody on eosinophils, airway hyper-responsiveness, and the late asthmatic response. Lancet. 2000;356:2144-8.

55. Flood-Page P, Swenson C, Faiferman I et al. A study to evaluate safety and efficacy of mepolizumab in patients with moderate persistent asthma. Am J Respir Crit Care Med. 2007;176:1062-71.

56. Haldar P, Brightling CE, Hargadon B et al. Mepolizumab and exacerbations of refractory eosinophilic asthma. N Engl J Med. 2009;360:973-84.

57. Nair P, Pizzichini MM, Kjarsgaard M et al. Mepolizumab for prednisone-dependent asthma with sputum eosinophilia. N Engl J Med. 2009;360:985-93.

58. Pavord ID, Agusti A. Blood eosinophil count: a biomarker of an important treatable trait in patients with airway disease. Eur Respir J. 2016;47:1299-303.

59. Global Initiative for Asthma. Global Strategy for Asthma Management and Prevention. 2016. Available at: www.ginasthma.org. [Accessed 11th May 2016.] 